\title{
SAN MARCO IN LE CORBUSIER, SAN MARCO IN BOGOTA
}

\author{
María Cecilia O’BYRNE \\ Los Andes University, Cra $1 N^{\circ} 18 A-12$, Of. K208, Bogotá, Colombia \\ E-mail:mobyrne@uniandes.edu.co
}

Received 13 November 2015; accepted 10 May 2016

\begin{abstract}
There are many ties between the monumental compound of San Marco in Venice and Le Corbusier. This article follows, studies and organizes these ties to link them to how he resolves the urban project for the Administrative Centre for Bogotá. In it, Le Corbusier leaves aside the isolated buildings that characterize his way of solving urban space, to use the chaos, the turmoil in the compound and uniformity in the detail, which are the features of San Marco: "An ideal and precise conclusion [that] under the rule of Louis XIV had been alrfeady formulated by Abbé Laugier", says Le Corbusier in Urbanisme.
\end{abstract}

Keywords: San Marco, Venice, Bogota, Le Corbusier, urban project, civic centre, administrative centre, modern architecture.

\section{Introduction}

Le Corbusier is tied to Venice in many ways throughout his life. This link has been investigated by many experts: (Talamona, Marida 2012; von Moos 1996; Petrilli 1999), among others. His first trip to Venice is between October 25 and November 8, 1907 ending what became known as the Trip to Tuscany (Gresleri 1987). The second is through books, initially, as a student in Chauxdes-Fonds, but mainly, with the studies done in 1915 in the Bibliothèque National of Paris where he carries out a detailed research on the history of the city to be used for his second book (Jeanneret 1992). In 1922 he comes back to Venice with his friend Raoul La Roche and publishes the first images of the city, collected during his studies, in Urbanisme (Le Corbusier 1925). In July, 1934 he returns to take part in the Convegno Internazionale d'Arte di Venezia, L'arte e la realità. L'arte e lo stato. The following year he publishes $L a$ Ville Radieuse (Le Corbusier 1935), where Venice appears in two pages as part of the presentation of the Urbanisation de la rive gauche de l'Escaut à Anvers (1933) project. New references to the city will appear in two other books Quand les cathédrales étaient blanches: voyage aux pays des timides (Le Corbusier 1937) and in Propos d'Urbanisme (Le Corbusier 1946). In 1952, Le Corbusier returns to Venice to lecture for students participating in a summer workshop in the CIAM School.
Le Corbuiser refers to the city based on his six actual trips, once through the books of other authors and four in his own books. A constant subject in the knowledge he acquired and the research undertaken of Venice is the monumental compound of San Marco. The subject of this article covers what he learned from the formal structure (Martí Arís 2006) of the famous Venetian compound and how such knowledge is connected to what Le Corbusier proposes for the Administrative Centre within the Master Plan for Bogota, Colombia in 1950-51. A knowledge that is also evident in the solution for the Venice hospital.

\section{The trips}

During his first trip to Venice, young Jeanneret is influenced by L'Eplattenier's lessons, his master-teacher in the school of Arts and Crafts in Chaux-des-Fonds, who in turn had been influenced, among others by John Ruskin's theories. ${ }^{1}$ Only one drawing of Venice shows his approach to architecture. It is a series of details of the Palazzo Ducale. Apparently, because of the rain, Jeanneret could not draw much more so he took a

\footnotetext{
1 Von Moos says: "Their subject matter ("the noble and fine harmony of the ample surfaces of the Dogs palace, or the hot cadence of the vaults and turrets of San Marco") is very Ruskinian in its Gothic focus. Jeanneret was particularly interested in decorative detail, such as the tracery or the capitals of the doges' palace (which Perrin sketched)", in: (von Moos 2002). Also see: (Hidalgo Hermosilla 2004).
} 


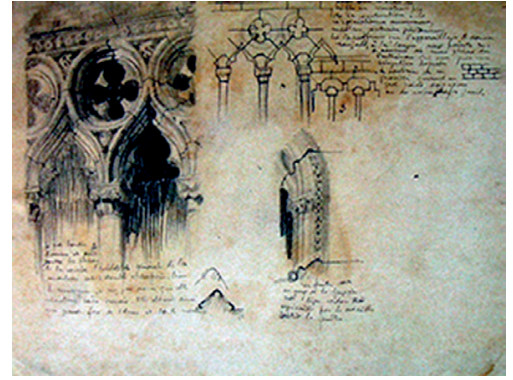

Fig. 1. Charles Edouard Jeanneret, Three details in the arcades of Palazzo Ducale (1907). @ FLC 2176

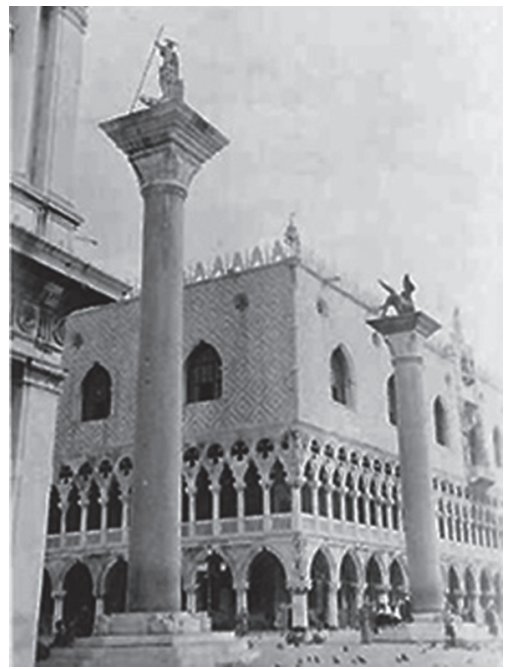

Fig. 2. Ch-E. Jeanneret. The lodge on the south east corner of Palazzo Ducale (1907). @ FLC L4-19-158

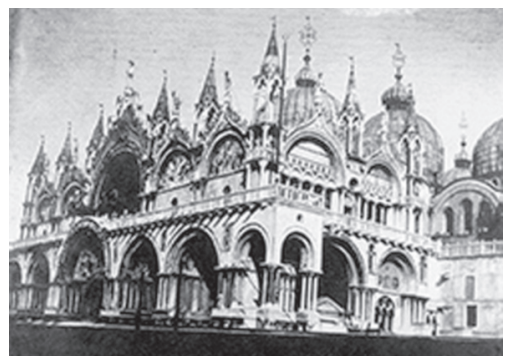

Fig. 3. Ch-E. Jeanneret, Southeast corner of San Marco Basilica (1907). @ FLC L4-19-161

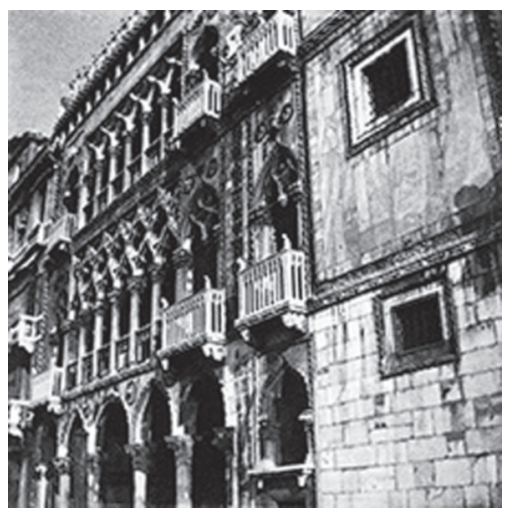

Fig. 4. Ch-E. Jeanneret, Façade of the Ca-d'Or's over the Canal Grande (1907). ๑ FLC L4-19-15 few photographs. There are images of the three buildings that interested him most as said to L'Eplattenier (Figs 1-4).

Palazzo Ducale, San Marco and the Ca'd'Oro, so many pearls. One observes as much as possible and tries to learn. ${ }^{2}$

In some observations from his trip to Venice, he notes:

This city seems to me not fit for a long stay. Too many moments of forced inactivity, those eternal boats that give it the flavor of great calmness. The crayons get worn out and the paper keeps being white.

During the trip to Tuscany and with the many drawings done by Jeanneret similar to Ruskin's, it is possible to see that an idea about architecture started to emerge that then, turned into one of the most celebrated statements of Le Corbusier which appears in four occasions in Vers une architecture: "Architecture is the wise game, correct and magnificent, of masses disposed under the light".

The experience of Venice will not only be present in Le Corbusier's projects in Bogota and Venice. It deeply influences his whole work. The group of images presented allows to highlight two facts that are common in these Venetian buildings and that Le Corbusier uses directly or indirectly along his work: on one side, the fact that the buildings in Venice are elevated on pilotis; and on the other, in elevation, the buildings that follow the model of the Palazzo Ducale are formed by three main bodies. The base is characterized by the predominance of emptiness versus fullness. The body is typified by the predominance of fullness versus emptiness; and the top that is just visible at a distance. Venice buildings have, in general, a free ground floor plan, with a few commercial premises assigned to services and storage areas. Both the Palazzo Ducale and the Ca-d'Or are exceptional examples. In the Baedeker guide that Jeanneret takes on his second trip to Italy (Baedeker 1910), ${ }^{3}$ the floor plan of the Palazzo Ducale shows that the ground floor is typified by a double gallery. Towards the exterior and the interior yard, it has a significant, open and covered free area added to the inner cloister while the floor plan occupies $100 \%$ of the area that can be constructed (Fig. 5). It is impossible to go through Venice and not be aware of the importance of theses

\footnotetext{
2 Jeanneret writes a letter, on November 1, to his master-teacher L'Eplattenier (FLC E2-12-12/15).

3 In 1907, according to Turner, Jeanneret travels with two books: Matins à Florence, by Ruskin and, Voyage en Italie by Hippolyte Taine. It is in the 1911 trip, known as Voyage d'Orient, that he takes the Baedeker guide (Turner 1971).
} 
buildings detached from the ground, even more if, as happened to Jeanneret in his first trip, it does not stop raining:

Venice hides from us; after 5 days of rain come 2 days of dense fog. Everywhere, water flows and flows; on Saturday, the sea invades even the Piazzetta. You can feel an itching all over your body: they are the fins of fish piercing... or simply mosquito bites? Two or three breakings through of the sun have given us the possibility of judging Venice under its beautiful appearance, the other night, we even attended to a genuine apotheosis, a dramatic sky well covered with dark clouds as a walnut and a yellow haze, and the shining sun next to the lantern of Saint Mary of Health; the sea, the sky, the houses, making a huge torch seen through tears. ${ }^{4}$

The Palazzo Ducale is a paradigm: the west and south façades of the famous building are built with light colored materials giving unity to the plane that in turn is clearly divided into two bands: in one, the void and shadow stand out; in the other, fullness and clearness take precedence (Fig. 6). The porticos of the base of the building and the gallery of level 2 have an aerial aspect, based on a double line of pillars. The building is always seen with a band of chiaroscuro, due to the shadows that the pillars and the covered space produce along the day. The drilled base sustains the solid brick and marble body where the main rooms of the building are located on level 3. The light colors of the brick and marble reflect the sunlight, making the body seem to float over the base of pillars. The body is hollowed by 7 large windows, on the west and south façades, that evidence the monumental height of the two main rooms of the building - that is, the Scrutiny room to the west and the Great Council to the south. The wall of the top body ends in a series of circular windows and by a group of pinnacles producing again an aerial aspect to the cornice of the building.

There is a similarity between the description of the west and south elevations of the Palazzo Ducale, and the generic description of the 4 elevations of the Ville Savoye, which in turn are divided into three horizontal bands. The first one is the ground floor with the portico that separates the box from the ground as if floating. The second is the first floor which is formed by the white wall, that surrounds all the perimeter of the house, hollowed by horizontal large windows of the covered or uncovered inside; and finally, the roof with pulled back volumes define the solarium. A descrip-

\footnotetext{
4 Letter from Jeanneret to L'Epplanenier (FLC E2-12-12).
}

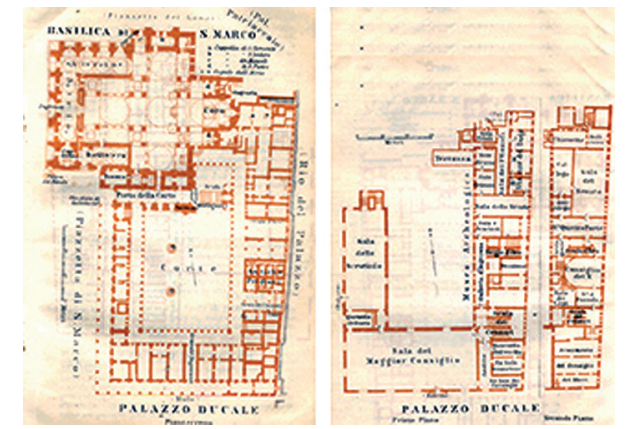

Fig. 5. Karl Baedeker, L'Italie des Alpes à Naples: plans of San Marco Basilica and Palazzo Ducale. @ FLC

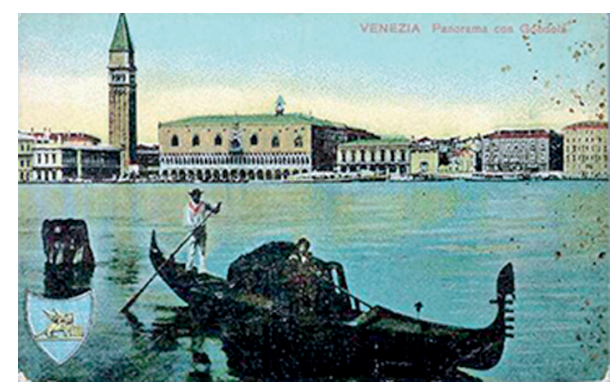

Fig. 6. Postcard where the south façade of the Palazzo Ducale, the Campanille and a gondola over a lake, can be seen. ( $s / f)$. (c) FLC L5-8-291-001

tion analogous to the Palace is possible for almost all Le Corbusier's projects elevated on pilotis.

It is possible to say that Jeanneret returned to Venice during the summer of 1915, but through books, sitting in the Bibliothèque Nationale de Paris, when he went to gather the graphic material needed for the book titled La construction des villes (Jeanneret 1992). The amount of material collected of Venice is enormous. Among all, the monumental compound of San Marco takes precedence, with the different public spaces that it comprises: the great piazza, the piazzetta, the dock or fondamenta, the south gardens and the Piazzetta ${ }^{5}$ dei Leoni next to the north façade of the basilica.

One of them is the floor plan of the compound (Fig. 7). The Basilica stands out and is followed clockwise by the Palazzo Ducale, the Zecca, the Biblioteca Marciana, Campenilli di San Marco, the Loggeta, Procuratie Nuove, the Ala Nepoleonica, The Procuratie Viecchi, and the Clock Tower.

The hatchings indicate two types of the buildings: one is the basilica that is highlighted in black as the element that organizes the compound, and second, all

\footnotetext{
5 It is important to leave the names of these spaces in Italian because in this language, it has been possible to find a term to explain the differences of scale and morphology of many of the public spaces that in other languages are mentioned in a more generic way.
} 
those buildings with a peripheric gallery that delimit the different premises (piazza, piazzettas, fondamenta, and garden). All the isolated elements are included (the campanille, the flag pedestals and sculptures), as they serve to indicate that their function is to delimit the voids that form the grid of the public spaces. Each one is differentiated by a few lines that indicate the main lines of the pavement, or elements such as fountains, flower beds, and so on. The compound is constituted by different types of buildings: on one side, two isolated buildings (the basilica and the campanille), and on the other, the buildings that delimit the void. In most of the cases they have irregular planes, where both the enclosing and the colonnade in ground floor, just allows to reveal, to the good observer, that it is a sum of different buildings constructed in different times.

In the analysis done by Jeanneret while drawing and which will become the drafts for the book that could only be published much later after his death, Schnoor narrates that young Jeanneret, who was strongly impacted by the books of Sitte and Brinckmann, wrote a chapter called "Des places", in which:

Le Corbusier fully backs Sitte's arguments; in them it was supported that a square was well resolved when it was closed, when the accesses to the square were not placed between the walls, but when they were born hidden near the corners (...), when historically monuments were not placed in the middle of the square and that the squares did not necessarily have

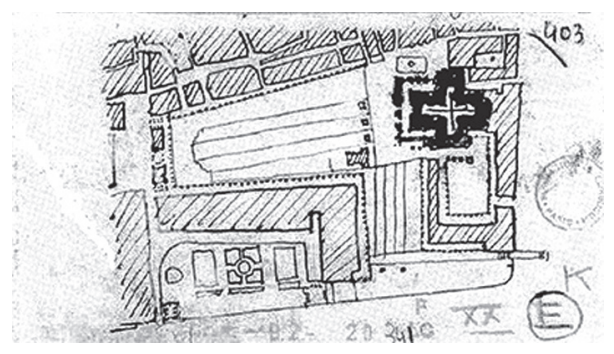

Fig. 7. Ch-E. Jeanneret, floor plan drawing of the San Marco monumental compound (1915). @ FLC B2-20-341

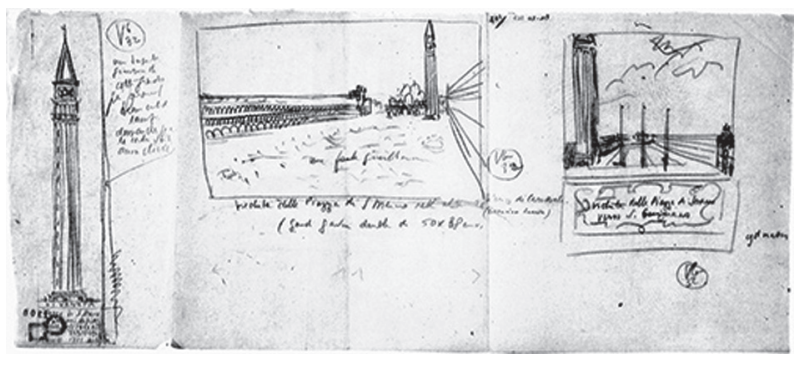

Fig. 8. Ch-E. Jeanneret, San Marco Piazza, and the Campanille seen from the west and east side of the square. ( ) FLC 2300 a rectangular shape; the small irregularities of historic squares, in fact, were not perceivable by the observer's eye and any way had, as a result, a well balanced compositions. To demonstrate the beauty of an irregular space of this type that hides perfectly the accesses, Le Corbusier signals Sitte's plan of the Piazza San Marco in the Venice (Schnoor 2012).

Jeanneret will reach his own conclusions, based on his studies. They indicate that among others, the famous squares including San Marco, the Palio in Siena, Piazza della Signoria in Florence and the Forums of Pompeii and Rome, leave the centre empty:

The study of the great famous squares [...] prove that the geometric centre of the squares is no longer occupied by fountains or statues, arches of triumph and obelisks. The centre of the square was always free; The monuments were all grouped along the walls of the squares (Jeanneret 1992).

For Schonoor, Jeanneret, also includes in the chapter about the urban square, when introducing the categories of "beauty and usefulness", an interesting approximation regarding the "character" of the square:

After stating that before projecting an architectonic compound of this kind, it is necessary to analyze the character of the impression that wants to be communicated. Le Corbusier asked himself if it was possible to achieve beauty in the project, by offering the possibility of choosing between beauty and magnificence, between the delicate and the colossal: delicate beauty against the great monumentality (Schnoor 2012).

One of the examples with which Jeanneret explains this ideas, is precisely with San Marco. He describes it as "a fairy tale spectacle in gold and marble, a fantastic eastern gem inserted in a sober classic box" (Jeanneret 1992). Jeanneret centres his attention on the piazza and campanile in two perspective drawings viewed from opposite sides: east and west, that is from the basilica, the figure on the right, and from the Napoleonic wing, the figure in the centre (Fig. 8). He says:

The campanille aims directly towards the sky, with its thick pointed needle, arrogant, uniform and red, providing the measure of an extreme life, the flexibility and splendor of San Marco causing, from the small carved white marble logia located at its feet, a total confusion with respect to its true dimension (Jeanneret 1992). 


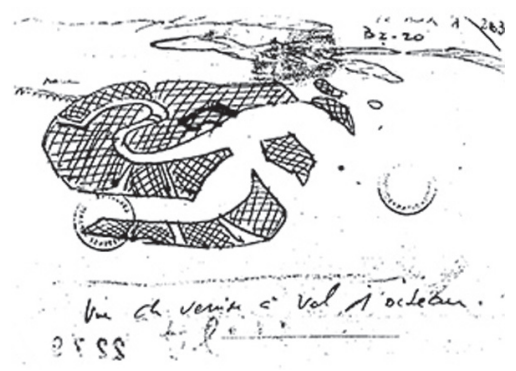

Fig. 9. Ch-E. Jeanneret, bird's eye view that shows the compound of isles that constitute the city of Venice. ( ) FLC B2-20-1-263

There are other drawings where San Marco appears, specially in a bird's eye view that shows the set of islands that constitute the city as a weave where canals and streets fuse and where three other elements are highlighted: the Great Canal, the Giudecca Canal, and the trans-lagoon rail bridge (Fig. 9).

In 1915, Jeanneret experiences Venice through books, sometimes recognizing it, sometimes discovering it, but always through the open public space of the city. For him, buildings are interesting since they shape the space of the city. Jeanneret focuses mainly on the analysis of the void. This is one of the issues that both from an urban and architectural perspective is one of the bases of Le Corbusier's research.

The third trip to Venice, from which there is a register in a sketch book, with several watercolor, pastel and pencil drawings, is done by Le Corbusier with his friend Raoul La Roche. In 10 drawings the San Marco compound never appears, but one of its neighbors on the lagoon does: San Giorgio Maggiore. The main issue is his interest to understand, in more detail, the silhouettes created by the urban compounds.

In 1922, Jeanneret sits back in some type of watercraft or from the fondamenta where on each side of the canal, he observes these city bands confined among the blue-grey sky and the lagoon. Thus, from the water, he discovers another Venice and another way of understanding the city: the urban silhouette created by the sum of several buildings that form a unit, made by different architects, masons or simple constructors. San Giorgio Maggiore will be drawn with few details, just with basic composition lines (Fig. 10).

It is not random that, during the trip to Venice, Le Corbusier is thinking and projecting his first city model. In the same Álbum La Roche, following the drawings of the trip to Venice and Vicenza, the next group of drawings corresponds to the Project for the The Contemporary City of 3 Million People exhibited in

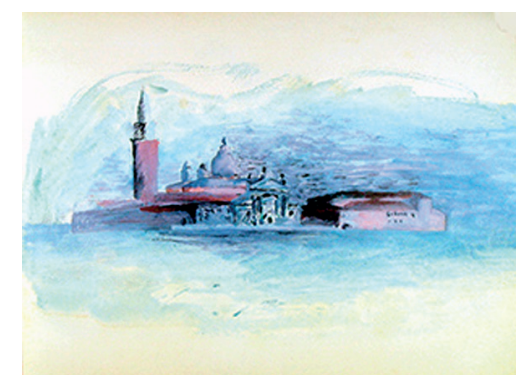

Fig. 10. Ch-E. Jeanneret, Album La Roche (1922): View from the pier next to the current Monaco Hotel in the island of San Giorgio Maggiore (p. 36). ๑ FLC

the Salon d'Automne in November 1922. The diorama that shows the general idea of the city is, in fact, a horizontal view of the compound where the skyscrapers stand out on an almost homogenous plan that the different dwelling buildings create.

In 1924 Le Corbusier publishes part of his city studies in Urbanisme, where he brings out two images of Venice: through two photos and a text, he synthesizes what he considers his main learning up to that date of the city on the lagoon. It is a detail of the building of the Procuratie Viecchi and a bird's eye view of the compound of Piazza San Marco (Figs 11, 12). The first serves as a heading for the beginning of a new chapter: "Classement et choix - (Décisions opportunes)":

Procuraties. Venice. The uniformity of the innumerable windows makes this great wall of Piazza San Marco act as the smooth wall of a great room. The multiplication of the same element gives the wall an unlimited but conceivable greatness summarized in a type of clear nature. The pigeons in San Marco add

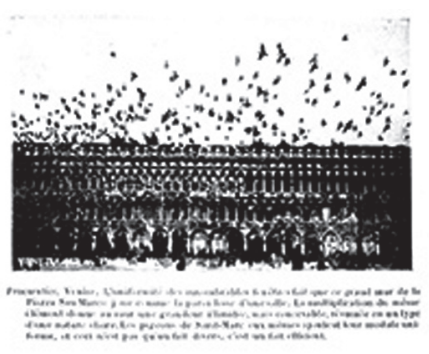

CLASSEMENT ET CHOIX

OECISIONS OPPORTUNES,

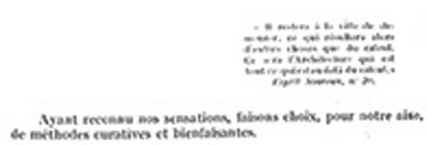

Fig. 11. Le Corbusier, Urbanisme (1924):C 63, beginning of chapter «Classement et choix ». () FLC 
their uniform module, and this is not a different fact, it is an efficient fact (Le Corbusier 1925).

The image of the Piazza goes with a statement of how the city has the right to be something more than "the palaces with corridors", and to know "the elements of an up to now unknown scale that will contribute with the grandeur of its dimensions" (Le Corbusier 1925).

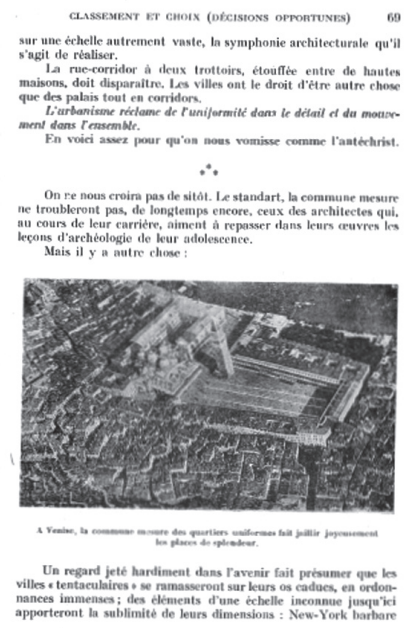

Fig. 12. L-C., Urbanisme (1924), page 69. @ FLC
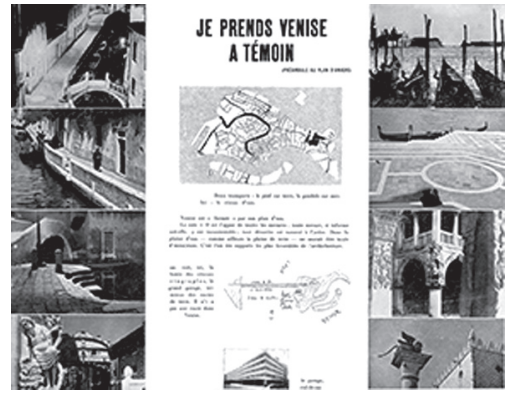

Fig. 13. L-C., La Ville Radieuse (1935): « Je prends Venise à Témoin », p. 268. @ FLC
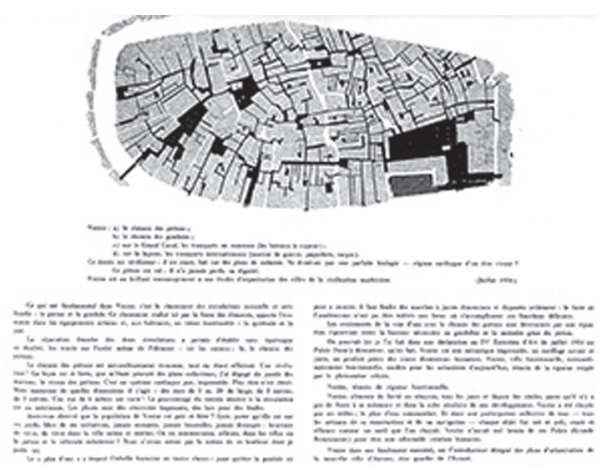

Fig. 14. L-C., La Ville Radieuse (1935), p. 269. @ FLC
In July 1934, Le Corbusier travels again to Venice to take part in a Convengo sull'Arte in the Palazzo Ducale. A year later, in La Ville Radieuse (Le Corbusier 1935), he uses a series of images and drawings of Venice to introduce the Urbanisation de la rive gauche de l'Escaut à Anvers (1933) project in two pages. In the first one, the title is clear: "I take Venice as witness" (Fig. 13). The images are forceful: in addition to the two lines of photos, there is a city plan, highlighting the canals, showing how the city connects to the mainland and the great parking of the Piazzale Roma. The group of images is the expression of the proof: Venice is a living example of a city that sets apart the pedestrian (white paths) from the vehicle (black roads):

\section{Venice:}

a) the path for pedestrians;

b) the way for the gondolas;

c) over the Great Canal, public transport (steamships);

d) over the lagoon, international transport (war navy, packet boats, freight ships)

This drawing is quite revealing; it is precise, made over land registry plans. ¿Does it not look like a perfect biology - the heart of a living system?

The pedestrian is king; he has never lost his dignity.

Venice is a powerful stimulus to our studies on the organization of cities in the machinist civilization (July, 1934) (Fig. 14).

There is no direct reference to San Marco, but there is to a feature of the city that makes San Marco a unique place: the separation between pedestrians and vehicles. What makes the monumental compound possible, as has been known for centuries, is this productive separation. It is where the different scales of squares with the dock or fondamenta can be used to dwell, live and enjoy greatly; it is because there, the pedestrian, as Le Corbusier says, is the king.

During World War II's previous and following years, Le Corbusier works intensively in the development of his city planning theories. He does it through his projects and in an important group of books. He will not go back to Venice until 1952, but meanwhile, he uses Venice in two of his publications as a living example of different qualities to take into account when thinking and building the city, In Quand les cathédrales étaient blanches: voyage aux pays des timides (Le Corbusier 1937), Le Corbusier makes a brief and forceful reference to the city:

If Venice, even oday, is the intact proof of a collective life, for us in France, we can draw on, 
in front of our eyes, the image of the time when the cathedrals were white.

In Propos d'Urbanisme (Le Corbusier 1946), Le Corbusier publishes 4 images sent in 1963 to the mayor of Venice. The fourth one is a perspective drawing of the Piazzeta, seen from the Clock Tower (Fig. 15). In the texts that go with the images, Le Corbusier emphasizes how the city is built through by overlapping periods, constructors, materials, shapes, and how it is possible to achieve unity based on this diversity. He also refers to the pedestrian and vehicle traffic imposed by nature: the water in Venice.

Venice offers a magnificent lesson of harmony. Nobody can deny the fact that this harmony is poetry that has been reaching the most varied nuances. Serenity in pleasure, productive diversity, unexpected stimuli, fineness and majesty spread all over the place. A symphony organized over a horizontal lagoon.

Le Corbusier travels again to Venice in September 1952 to lecture for a group of students doing a workshop in the CIAM School. The images of Venice he leaves from this trip are the drawings done during the conference (Figs 16, 17). Le Corbusier draws the first while explaining it:

Venice is like a water level. You need the storms of life, the difficulties of a business, of having two things to build: a water level and a plumb. Well, the preferred water level in Venice is given to us and with its cause. Venice has been built with such clear elements that we can see all the phenomena that emerge and appear in architecture and city planning [...], there is a variety of vertical shapes, domes, roofs, bridges... there is this extraordinary thing, that extraordinary thing that the gondola is, for centuries an absolutely wonderful artifact and, you know, the consequences of the gondolas are known: the bridge which is an integrating element for the gondola to pass, with the gondolier above the passenger and the pedestrian. There is what I call team, on the water, these wooden poles that support the gondolas, and which are quite useful because they allow to park the gondolas. And then, they are such extraordinary things in Venice that are the "stairways to heaven" in certain essential points of the city. You will immediately recognize these "stairways to heaven", they are the bridges, some bridges, on which the crowds walk; they are surrounded, I repeat once more, not by buildings but by houses that have the privileged game of their reflection on the water as decoration for man (Le Corbusier 1952).

Le Corbusier follows all the description of the city to introduce the central issue of his lecture: The Sector and the 7 Vs:

I will show you Chandigarh's plan, but initially I have to explain that at the same time, I have intervened in the city planning of Bogota, in South America. This allowed us to establish a new factor to the modern city: a unit of magnitude: the sector. This sector is a direct product

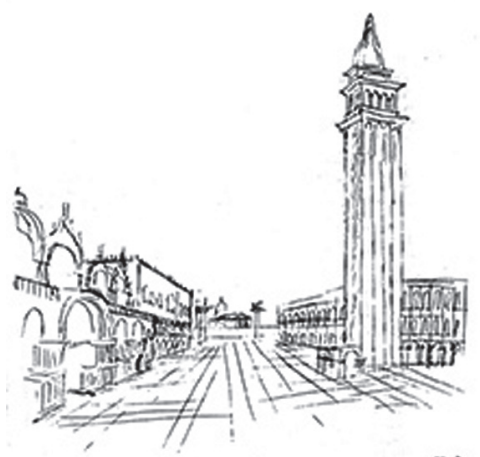

Fig. 15. L-C., Propos d'Urbanisme (1946): V 17 view of the San Marco square drawn in 1915 in the Bibliothèque Nationale de Paris. ( ) FLC

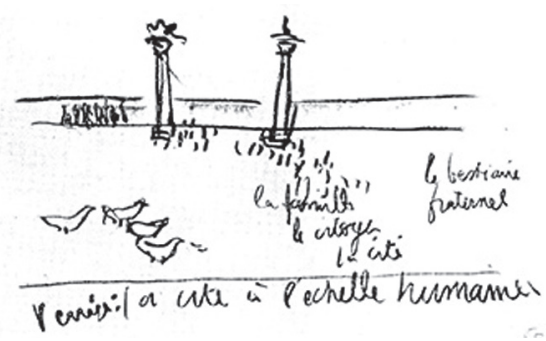

Fig. 16. L-C., «A propos de Venise» (1952): “Venice, the city on human scale, with the towers that delimit the Piazza and the Piazzetta of San Marco". @ FLC

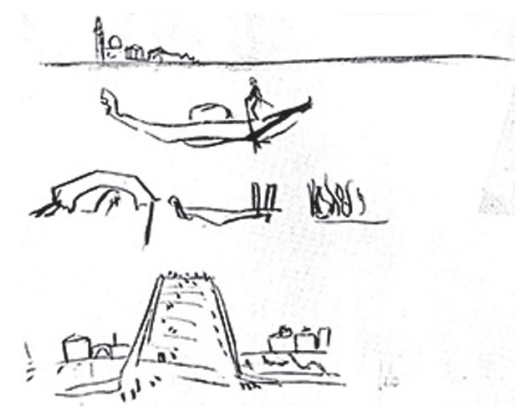

Fig. 17. L-C., «A propos de Venise» (1952): San Giorgio Maggiore compound viewed from the lake with a gondola at the forefront, on the first third top part of the paper. In the center, bridge and pier. @ FLC 


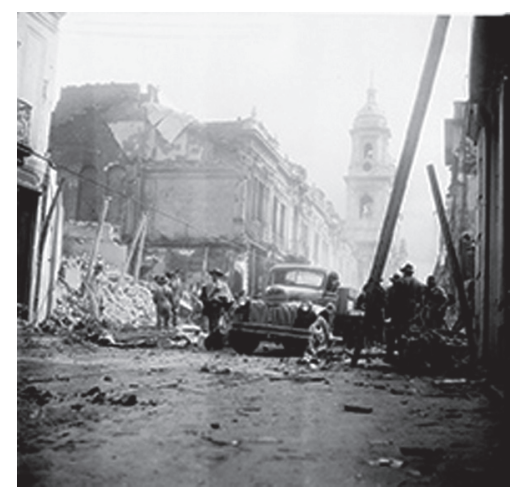

Fig. 18. Photograph of the wreck left after April 9, 1948 on Carrera 7a (Public domain)

of the requirements to order the automobiles leaving a space between streets, analogous to the one in Venice between the canals and other water surfaces. The research led to a result that is a law, a rule, the law of the $7 \mathrm{Vs}$ (Le Corbusier 1952).

It is Stanislaus von Moos who synthesizes in three aspects what le Corbusier learns in Venice:

In later years, Le Corbusier referred to Venice as a model for the solution of the widest range of architectural and urban problems: repetition used to organize the surfaces of large buildings (the Procurazie Vecchie); separation of traffic lines to organize circulation (the canals); and the acceptance of tension and contrast of forms and styles within an urban whole, as opposed to superficial "harmony" (Piazza San Marco) (von Moos 2002).

\section{Le Corbusier's Plaza de Bolivar in Bogota}

Le Corbusier traveled to Bogota five times, between 1947 and 1951 with a total stay of 77 days. The purpose was the project of the Master Plan for the city contracted in 1949 and finished a year later. The Project will have as one of its main features to recommend an administrative centre, as part of the general proposal for the city. The most important reason for this project to be a fundamental point of the plan is that on April 9, 1948, almost a year after Le Corbusier's first visit to the city and in the midst of the Panamerican Conference being celebrated in those days, a great fire devastated a great part of the buildings downtown (Fig. 18). ${ }^{6}$

The version of the square of Plaza de Bolivar analyzed here is the one presented by Le Corbusier in 1951 in Hoddesdon in the CIAM VIII in a MARS Grid format (Fig. 19). ${ }^{7}$ Of all these plans, let us see two in detail: the floor plan that is developed to submit the road plan, in the chapter "The Heart-Layout", includes antique buildings, the new ones proposed and some section

\footnotetext{
6 This was as a consequence of the popular riot organized in response to the assassination of the popular leader and candidate to the Presidency of the Republic, Jorge Eliecer Gaitan.

7 The plans that are part of the grill are in the archives of the Fondation Le Corbusier in Paris in a folder titled "Ascoral. Centro Administrativo, Bogota, Colombia. Plan Piloto 1950 Le Corbusier; Consultores: Wiener y Sert; Dirección del Plano Regulador, Arbeláez y Pizano", under the names of the R2-15-1 to R2-15-17. See: (O’Byrne et al. 2010).
}

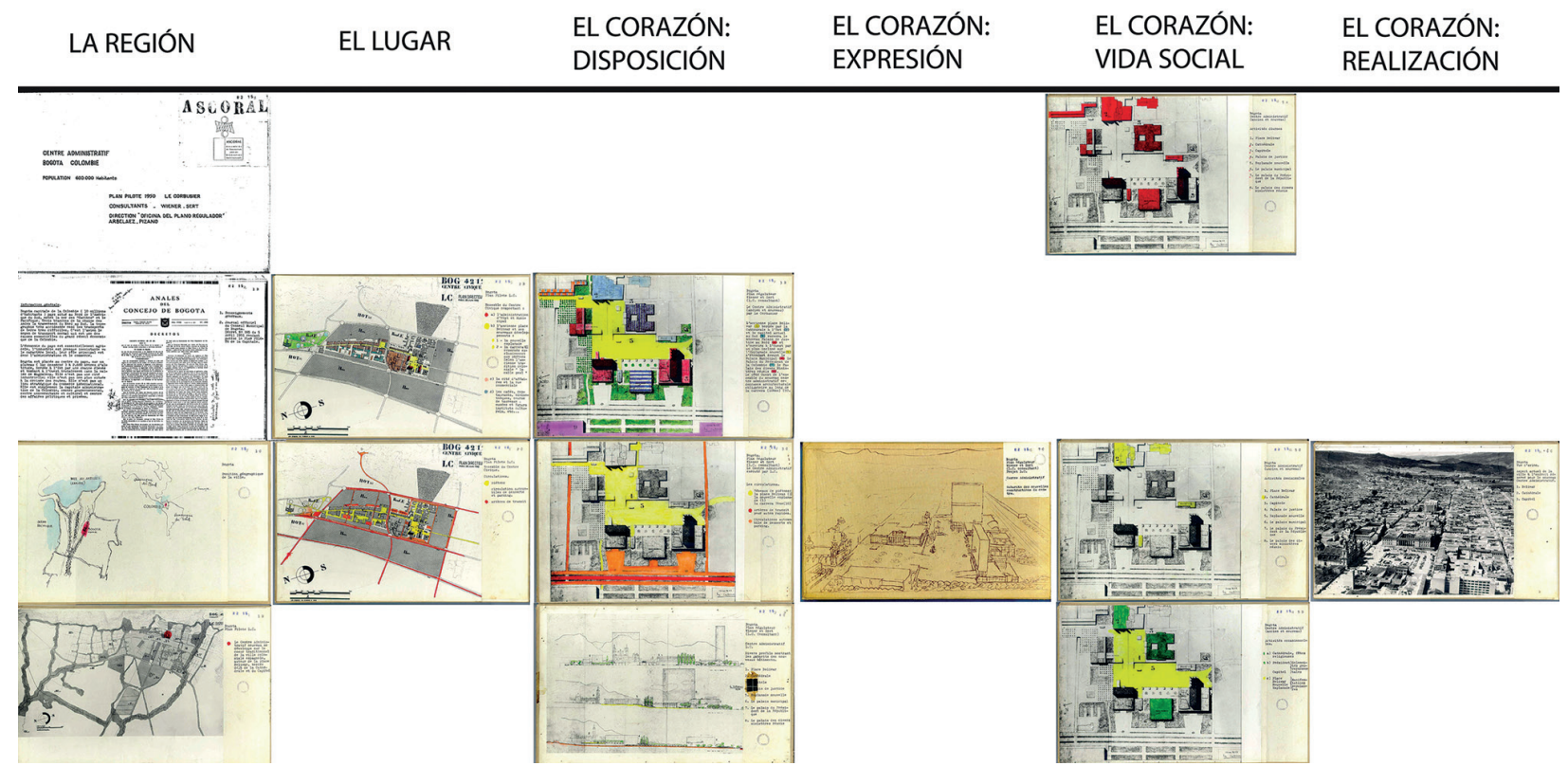

Fig. 19. Le Corbusier, Grille MARS: Civic Center in the Master Plan for Bogota, presented in the CIAM VIII in Hoddesdon, 1951 ○ FLC 
that allow to recognize the idea of city planning he is putting forward in three dimensions.

As part of the proposal, Le Corbusier selects several historical buildings that are fundamental to create a balance between what exists and what is proposed. All these are presented, plaster made, in the model of the Civic Centre while the buildings proposed are made of plywood. Le Corbusier says:

The Civic Centre gathers, in a spiritual and material harmony, the collective functions capable of expressing the spirit of a social group, of a city, or of a society. It connects the past to the present. It constitutes the non-ruptured, not neglected history of the city (Le Corbusier 2010).

Through the graphic material it is possible to understand that Le Corbusier's proposal is based on adding a great esplanade on the eastern side of the historic square (Figs 20-22). He also uses small squares to give access to the square through the corners, especially the northeast and southeast ones. He resorts to sculptures, vegetation, ramps, flag pedestals, porches and other architectonic elements, to characterize a space that although all its sides are defined and limited by isolated buildings, it maintains its closed and walled character of the foundational square in all the compound. But, to understand the proposal, it must be seen having in mind that most of the historic buildings are located on the southeast of the square while the proposed buildings are located in the northeast and southeast.

The Plaza de Bolivar that Le Corbusier draws is delimited by two historic buildings: The Capitol, designed by architect Thomas Reed (1848-1926), and the Cathedral, designed by Fray Domingo Petrés (1807 and 1823). To the north is the proposed Justice Palace, whose access is through an off-centreed ramp or platform towards the west. The pedestrian use of the square is separated from the new Palace with two water mirrors or landscaped zones that draw, in floor plan, the original line of the colonial layout of the block demolished. Pulling back the building from the original wall allows to have, as a leading hallway to the major square, a small square on the northeast, at the point where Carrera $7 \mathrm{th}^{8}$ begins towards the north previously known as Calle Real, called by Le Corbusier Grand Rue.

The small square created between the Palace of Justice and the Cathedral, as a hallway to the major square, doubles to the east with a small park delimited

\footnotetext{
8 I use the terms Calle and Carrera in Spanish since this is necessary to understand the order in Bogota: Calles are roads that run east-west and Carreras cross the city from north to south.
}

by a two floor narrow stepped commercial building on Carrera $7^{\text {th }}$. However, on reaching the corner, the volume is drawn back one bay to leave this gardened space free. The west side of Carrera $7^{\text {th }}$ has no buildings. The historic boundary is maintained with a forested zone

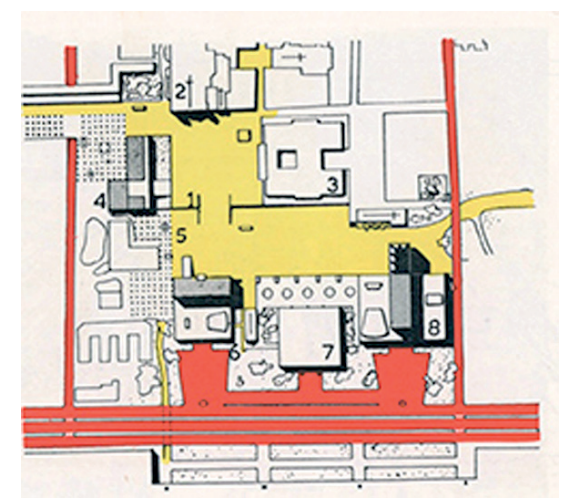

Fig. 20. L-C., the Civic Center, for the Regulator Plan of Bogota by Wiener and Sert (Le Corbusier Consultant), May 17, 1951. (c) FLC R2-15-8

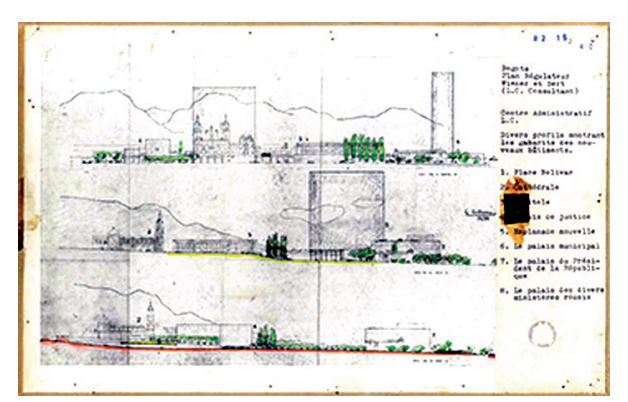

Fig. 21. L-C., the Administrative Center, for the Regulator Plan of Bogota by Wiener and Sert (Le Corbusier Consultant), May 7, 1951: several sections show the new buildings. @ FLC R2-15-9

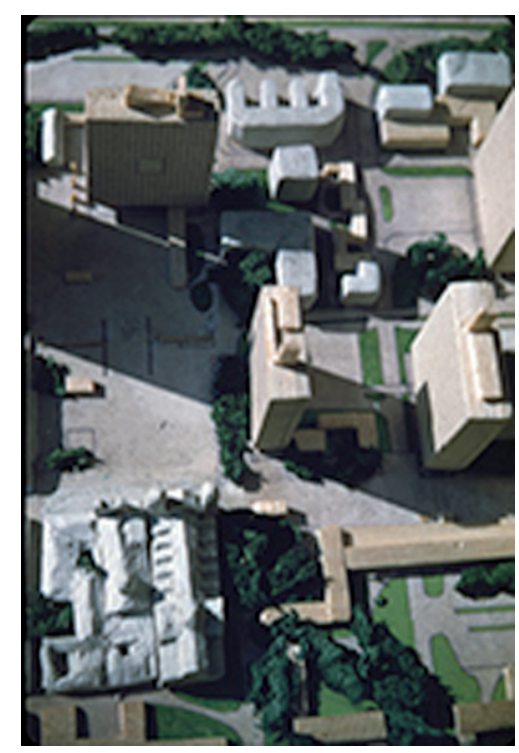

Fig. 22. L-C., Master Plan for Bogotá, 1950: detail of the model of the Civic Center. (c) FLC 
which formes a hypostyle hall of trunks and a medium height tree canopy on the north façade of the Palace of Justice. It is only interrupted when leaving the vehicle tunnel that allows Calle $12^{\text {th }}$ to be one of the connectors for the automobiles of the public administration sector. Hence, Le Corbusier maintains the profile of what used to be the functional heart of the city, but with other materials, and breaks the corner, placing a sculpture on the axis of Carrera $7^{\text {th }}$.

The new buildings are surrounded by garden zones, that constitute a sort of wall on the east side of the esplanade. It is a great forum accessed through a ramp, located on the symmetry axis of the original square, that defeats the natural slant there is between Carreras $7^{\text {th }}$ and $8^{\text {th }}$ (Fig. 23). On both sides of the stairway, perhaps a commercial plinth is formed, because if we observe the section carefully, it is possible to perceive an arcade or gallery formed where the square and the esplanade meet and which was drawn in a sketch of the first version of the square.

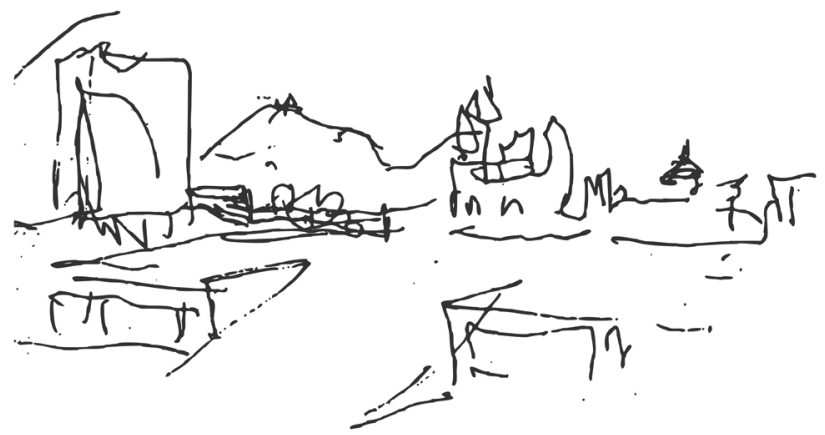

Fig. 23. L-C., sketch of the project for the Plaza de Bolívar done in situ, Bogota, September 20, 1950. (c) FLC Carnet D15-93

The succession of small squares, squares and an esplanade is a legacy of the form by which the urban space of the San Marco monumental compound in Venice is conceived: different buildings placed in such an order that in spite of the differences in shape and figure, creat an entire space, where the void serves as a link to give shape to the compound. It is a series of buildings of which Le Corbusier dreamed building only one: the Ministries.

Le Corbusier places three different buildings on the east side of the esplanade for Bogota to form his novel wall: two platform-towers to home the City Hall and the Ministries and an isolated pavilion for the President's Palace.

For the city hall, he uses a platform-tower where one and the other are on the same plan of the façade with respect to the esplanade and where the only element that stands out is a ramp placed towards the north part of the building. From the square, it is not be easy to understand that it is a platform-tower, because the tower, located east-west lengthwise, coincides with the level of the platform. But it is separated from it on the ground floor through an open portico. This makes the open space of the square and esplanade to continue above the roof of the platform where two volumes of auditoriums form two open air stages. A colonnade allows the evening sun to continue lighting up the foundational square. To the north, the tree garden is replicated forming the boundary wall of the antique decumanus, Calle $11^{\text {th }}$.

On the south side, the City Hall building is next to the Concepción Church. It is exempt in the space, creating a dialogue with its new neighbor and maintaining, the south face on Calle $10^{\text {th }}$. A landscaped space, now without ordered trees, serves as lining between the church and the Presidential Palace: it is a box drawn back with respect to the face formed by the City Hall and Ministries' buildings. Le Corbusier manages to keep them aligned with the flag square that precedes the Palace and where the pedestals serve to provide continuity to the face. A second row, this time of trees, allows the Palace, though it is part of the compound, to provide the possibility of some intimacy away from the presence of the public. From the perspective drawing one can identify that he was thinking of a garden terrace with a pavilion to crown it with different types of enclosures to make it it more or less permeable at different points.

A landscaped strip on Calle $9^{\text {th }}$, which coincides with the old Calle $9^{\text {th }}$, separates the Presidential Palace from the Ministeries. There is a very different platform-tower from the one of City Hall: the tower, with north-south façades, is located amidst the platform and stands out forming an entrance portico. It is like that of the Ministry of Education and Health in Río de Janeiro, projected by Lucio Costa and Oscar Niemeyer and with Le Corbusier as consultant. The portico, with an open and covered space, defines the south side of the esplanade. The entrance ramp to City Hall serves for the same purpose, but on the north side. The Ministries tower, approximately 90 meters high, would be built with windows that do not need brise-soleil while the one of City hall, of approximately 75 meters high, will need them to counteract the strong morning and afternoon light. Thus, it must be placed, against what theory says, to "close" the space of the square that now is doubled. Visually it continues towards dusk through the gap of columns that is formed between the platform and the tower. The same resource is not used in the Ministries, though the portico of the tower 
that stands out allows sight at ground level, to drift towards the mountains of the south of Bogota.

Santa Clara Church, located in front of the Ministries, is elevated on a type of podium. It has a row of slender and tall cypress type trees, placed on the west side of the Capitol, on an artificial mountain that separates them from what appears to be the equestrian sculpture of Bolivar made by French sculptor Manuel Fremiet in the late $19^{\text {th }}$ Century. The tour from left to right ends in the Capitol, which has, for the first time, a free back space characterized by a small garden surrounding the Astronomical Observatory also exempt in a great open space. On the south façade, Le Corbusier places a pedestal for another sculpture, on the corner of Carrera $7^{\text {th }}$ and Calle $10^{\text {th }}$. It indicates the pedestrian that at this point, the square closes while on the other side, it opens. This highlights how the square serves as a breaking point of a pedestrian route that though it reaches the north through Carrera $7^{\text {th }}$, he will come out on the south through Carrera $8^{\text {th }}$ or vice versa. A diagonal.

When observing the monumental compound, the pedestrian coming in through Carrera $8^{\text {th }}$ on the south, between the tower of the Ministries and the park of the Observatory, he enters in an analogous way to what happens on the north side. He comes in through a small square that serves as an ending point for the pedestrian path that links the centre to the south. It is only insinuated; it is curvilinear. The next premise, defined by a portico and the platforms of the Ministries and Santa Clara Church, forces the person who enters through this side. He looks towards the north, and following his eyesight toward the esplanade, does not discover yet, the presence of the historic square. It is only viewed once passed the Capitol building. A great perspective view opens then, in a diagonal, where the square is formed by three elements that constitute the new landscape: the Cathedral, Monserrate Mountain and the Palace of Justice. Here they complete a sight in which the antique and the modern come together with nature in an unprecedented landscape of a balance among the three parts. This would seem could not come into a dialogue; here, however, quite in the way of Le Corbusier, they form a unit.

There is little else to highlight from the plan: on the west side of the palaces, which form the façade of Carrera $10^{\text {th }}$, the section proposed by Le Corbusier will be quite different from the one constructed of 92 meters wide. He differentiates the road ways of heavy traffic from those of slow traffic through which one can access the parking bays of each of the new buildings. They create, again on this side, a face but one far from the road which in turn is so full of cars as it is of vegeta- tion. The pedestrian just has to walk to Carrera $10^{\text {th }}$ to take public transport. While he has gone through the new administrative centre, he has done it, as in Venice, through streets and squares where he has been the king.

\section{Conclusion}

To sum up this visit, we can find that, in a similar way to how the monumental compound of San Marco in Venice is toured, Le Corbusier is able to give each sphere of public and open space some specificity that characterizes it, without losing de idea of a compound. A compound thought, as he would do later in Chandigarh, on a very different scale to the one in Bogota. It is open, public, and without limits for the citizens to tour through each side, discovering, as we have done during this tour, the wonders of what walking freely through the heart of the city means. An analogous heart to the Venetian one, but that was not built. It is part of Le Corbusier's thinking announced in the Technical Report of the Plan, in the following statement:

... the revolutionary work is revealed through a highly traditionalist character. Because it reencounters the roots of things, because it designs again its true axis (Le Corbusier 2010).

After carefully pass through each of the compounds, the historic and the modern, the article identifies issues that Le Corbusier learned and took from Venice to be applied in Bogotá. That is what was called the structural form at the beginning of this article:

- The separation of pedestrians and vehicles, that allows to have three main entrances to the compound, with many others of different scale or importance to the group of open public spaces.

- The final result is a succession of open spaces of different scales. The esplanade is analogous to the Piazza, while the historic Plaza de Bolivar is fulfilling functions similar to the piazzetta San Marco, and the small square that serves as a link between the Carrera $7^{\mathrm{a}}$ and the Plaza is similar to the piazzetta dei Leoncini.

- Le Corbusier, knowing that the perception of the human eye is at $1.65 \mathrm{~m}$ average, indifferent of the two towers that are part of the whole in Bogotá, creates a continuous base, with the average height of the existing buildings, achieving continuity and alignment with different elements, even if, as in the case of the bases for banners, is not a continuous volume.

- The new buildings for Bogota are isolated and those historical that are part of the project, remain isolated too. But the result is a restrained space, enclo- 
sure, as in Venice. The buildings and the gardens delimit the different open spaces, which are also characterized with the use of sculptures, gardens, fountains, etc.

- In Bogotá, Le Corbusier achieves, as in Venice, continuity despite the diversity, where buildings of different ages, of different types, manage to build a whole, a unity.

\section{References}

Arbeláez, C. 1952. Junio. El plan regulador de Bogotá. Revista Pórtico, 8.

Baedeker, K. 1910. L'Italie des Alpes à Naples. Leipzig-Paris: Baedeker-Ollendorf.

Brinckmann, A. E. 1908. Platz und Monument. Berlin: Ernst Wasmuth A.-G.

Brooks, H. A. 1985. Jeanneret e Sitte: le prime idee di Le Corbusier sulla costruzione della città, Casabella 514: 40-51.

Foundation Le Corbusier. Paris, France.

Gresleri, G. 1987. Le Corbusier: il viaggio in Toscana, 1907. Venezia: Marsilio.

Hidalgo Hermosilla, G. 2004. La constatación de una aprendizaje. El viaje a Italia en 1907 de Ch-É. Jeanneret, in AA.VV., Massilia, Annuaire d'Études Corbuseennes. Sant Cugat del Vallès: Associacio d'Idees, Centre d'Investigacions Estetiques.

Jeanneret, Ch.-È. 1992 [1915]. La Construction des villes. Paris: Marc E. Albert Emery, L'Age d'Homme-FLC.

Le Corbusier. 1925. Urbanisme. París: Crès.

Le Corbusier. 1935. La ville radieuse. Boulogne-sur-Seine: Editions Vincet Fréal \& Cie.

Le Corbusier. 1937. Quand les cathédrales étaient blanches: voyage aux pays des timides. Paris: Plon.

Le Corbusier. 1941. Sur les 4 routes. Paris: Gallimard.

Le Corbusier. 1943. La charte d'Athenes. Paris: Plon.

Le Corbusier. 1946. Propos d'Urbanisme. Paris: Bourrelier et Cie.

Le Corbusier. 1952. A propos de Venise. Conferenza di Le Corbusier tenuta agli studenti della scola del CIAM, a Venezia. Venezia Architettura, 7-9.

Le Corbusier. 1953. Euvre complète 1946-1952. Zürich: Girsbesger.

Le Corbusier. 2010 [1950]. Le Corbusier en Bogotá 1947-1951. Elaboración del Plan Regulador de Bogotá. Establecimiento del Plan Director por Le Corbusier en París, 1949-1950 (edición facsimilar) (Vol. 1). Bogotá: Universidad de los Andes.

Le Corbusier et Pierre Jeanneret. 1937. Euvre complète 19101929, Vol. I. Zürich: Girsberger.

Le Corbusier et son Atelier rue de Sèvres 35. 1965. Euvre complète 1957-1965. Zurich: Girsberger.

Martí Arís, C. 2006. Las variaciones en la identidad: ensayo sobre el tipo en arquitectura. Barcelona: El Serbal.

O’Byrne, M. C. 2008. El Proyecto para el Hospital de Venecia de Le Corbusier. Barcelona: UPC-ETSAB.
O’Byrne, M. C.; Martí Arís, C., et al. 2010. Le Corbusier en Bogotá, 1947-1951. Precisiones en torno al Plan Director. Bogotá: Universidad de los Andes.

Petrilli, A. 1999. Il testamento di Le Corbusier. Il progetto per l'Ospedale di Venezia. Venezia: Marsilio.

Schnoor, C. 2012. L'Italia come modello di spazio urbano: i riferimenti a Venezia, Firenze e Roma ne La Construction des villes, in M. Talamona (Ed.). L'Italia di Le Corbusier. Milano: Electa, 175-187.

Sitte, C. 1889. Der Städtebau nach seinen künstlerischen Grundsätzen (Construcción de ciudades según principios artísticos). Viena.

Talamona, M. (Ed.). 2012. L'Italia di Le Corbusier. Milano: Electa.

Turner, P. V. 1971. The education of Le Corbusier. Boston: Harvard.

Vargas, H. 1987. Le Corbusier en Colombia. Bogotá: Cementos Boyacá.

von Moos, S. 1996. La lezione di Venezia, in Le Corbusier, Album La Roche. Milano: Electa.

von Moos, S. 2002. Venice. In AA.VV., Le Corbusier before Le Corbusier-Applied arts - Architecture - Painting Photography - 1907-1922 (pp. 150-153). New York-BadenNew Haven-London: The Bard Graduate Center for Studies in Decorative Arts, design and Culture-Langmatt MuseumYale University Press.

von Moos, S. 2012. Alle Venezia. Le Corbusier, il turismo e la "crisi dell'utopia", in M. Talamona (Ed.) L'Italia di Le Corbusier. Milano: Electa, 201-218.

\section{MARIA CECILIA O'BYRNE}

Architect (1988) from Los Andes University, with PhD. (2008) and Master of Architecture (1993) from the Polytechnic University of Catalonia. Actually is Associated teacher at the Department of Architecture of Los Andes University in Bogota, where is the director of the Research group: Project, Architecture and City. Is the author and/or editor of books like: Le Corbusier in Bogotá, 1947-1951, Vol. 1 \& 2 (2010); Espirales, laberintos, molinetes y esvásticas en los museos de Le Corbusier, 1928-1939 (2011); and Le Corbusier y la arquitectura instalada en su sitio: los museos de Ahmedabad y Tokio (2015). 